
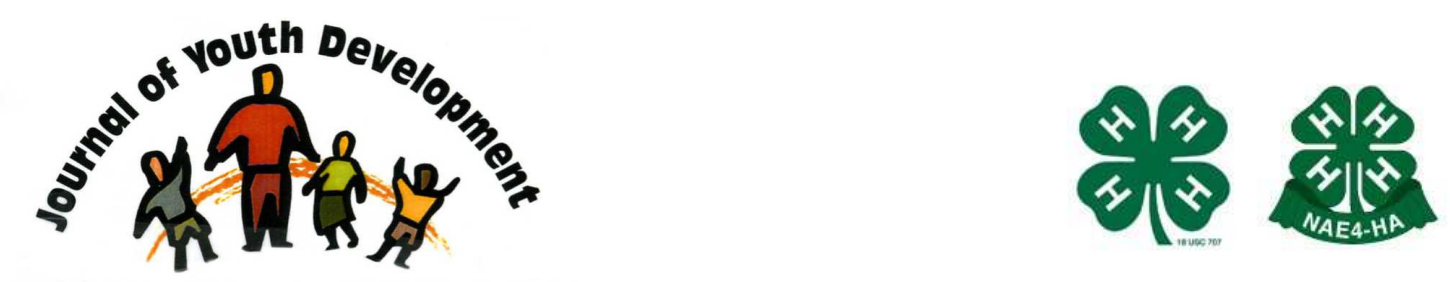

Bridging Research \& Practice

\title{
Perceptions of 4-H Professionals on Proposed Solutions Towards Diversity Inclusive 4-H Youth Programs
}

Douglas D. LaVergne

Texas A\&M University-Commerce

Commerce, TX

doug.lavergne@tamuc.edu 


\title{
JOURNAL OF YOUTH DEVELOPMENT \\ bridging research and practice

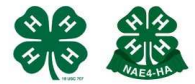

Volume 10, Number 1, Spring 2015

Article 151001RS003

\section{Perceptions of 4-H Professionals on Proposed Solutions Towards Diversity Inclusive 4-H Youth Programs}

\author{
Douglas D. LaVergne \\ Texas A\&M University-Commerce
}

\begin{abstract}
This paper highlights findings from a web-based questionnaire used to explore and analyze [State] 4-H youth professional's perceptions on proposed solutions to increasing diversity inclusion - particularly among youth of color and youth with disabilities - in 4-H youth programs. Descriptive statistics were used to report demographic and personal characteristics along with percentage agreements on proposed solutions. Respondents agreed that: "County 4-H youth professionals should become familiar with the youth with disabilities represented in their counties in order to promote an atmosphere of acceptance and cooperation;" "4- $\mathrm{H}$ youth instructional materials should reflect the diverse society that 4- $H$ youth programs have;" and "for youth to become interested in joining 4- $H$, parents, 4-H youth professionals, and policymakers must develop strategies to address the different learning styles of all youth." Finally, recommendations were identified for professionals who want to increase diversity inclusion in their respective 4- $\mathrm{H}$ youth programs.
\end{abstract}

\section{Introduction/Background}

Although National 4-H enrollment numbers indicate increases in the participation of youth of color and youth with disabilities, both groups continue to be underrepresented in comparison to national demographic numbers. Data from current enrollment reports indicate that while 34\% of all 4- $\mathrm{H}$ youth are persons of color, the same population makes up over $44 \%$ of eligible $4-\mathrm{H}$ youth participants enrolled in our nation's schools (Snyder, \& Dillow, 2011; 4-H National Headquarters, 2012). In regards to youth with disabilities, the number of 4-H eligible youth with disabilities in public schools represents over $13 \%$ of the total enrollment with 31 states having an overrepresentation percentage greater than the national average (Snyder, \& Dillow, 
2011). Brault (2012) reported that nearly one of every 5 people in the United States ages 5 and older have some form of disability with people of color having larger proportions as compared to non-Hispanic White Americans. With knowledge of the demographic shift among America's youth, agriculturally based programs such as 4-H and the National FFA must develop strategies for the successful recruitment of underrepresented groups (Stair, Seevers, \& Moore (2012).

A thorough review of literature reveals that Extension programs have continuously sought ways to provide programming to culturally diverse audiences. As Nicolas, DeSilva, Houlahan, and Beltrame (2009) stated, "given the increasing ethnic and racial diversity of youths in the United States, researchers must be conscious of how youth are being recruited and retained..." (np). Indeed, researchers have sought steps to determine the impact of such initiatives and the perceptions of those individuals responsible for action. In a study analyzing the perceptions of North Carolina 4- $\mathrm{H}$ youth Extension professionals regarding solutions to increase underrepresented youth participation, Alston and Crutchfield (2009) discovered that 4-H extension professionals agreed that the incorporation of ethnic adult role models, non-traditional based programs, educationally-based recruitment initiatives would increase underrepresented youth participation in 4-H programs. In addition, the researchers discovered that respondents agreed that the traditional perception of agriculture continues to be a deterrent to underrepresented group participation. In a similar study to determine West Virginia Extension professionals' perceptions of the benefits and barriers to underrepresented groups in 4- $\mathrm{H}$ youth programs, LaVergne (in-press) discovered that Extension professionals agreed that there are benefits for students of color and students with disabilities in 4-H programs which included leadership opportunities, improved social relationships (among other youth), career exploration opportunities, increase academic improvement, and positive community relations. The researcher also discovered that perceived barriers such as the lack of information about 4-H programs, the absence of role models, the perception of $4-\mathrm{H}$, and the parental attitudes were possible reason for underrepresented group participation.

Because 4-H Extension professionals provide programs to all people, the importance of understanding the effect of youth with disabilities in 4-H programs along with developing strategies for successful inclusion is critical. In a study to assess state 4-H Leaders' perceptions toward the involvement of special needs youth in 4-H programs, Stair, Seevers, and Moore (2012) discovered that only $13 \%$ of participants reported that their states had a tracking system for special need students in 4-H programs. In regards to personnel training for accommodating special needs youth, $45 \%$ of participants indicated that programs were offered. The researchers also discovered that over $95 \%$ of respondents indicated the use of accommodations for special needs youth which included specific program modifications (per individual), collaborating with program staff (to aid special need individual), and case-by-case modifications (Stair, Seevers, \& Moore, 2012). Goble and Eyre (2008), in their approach to assisting Extension professionals improve their understanding of special needs youth through sensitivity training activities, noted that hands on training workshops are more effective than lecture awareness programs when helping 4-H professionals become more sensitive to the needs of youth with disabilities.

Mpofu, Ingram, and Radhakrishna (2010) examined perceptions of 4-H Extension educators and volunteer leaders towards the inclusion of special needs youth in 4-H programs, specifically examining youth with Attention Deficit Hyperactive Disorder(s) (ADHD). The researchers discovered that Extension educators and volunteer leaders:

a) found it challenging to work with youth with ADHD due to the lack of training,

b) had positive perceptions toward youth with ADHD,

c) believe that all youth benefit from inclusion, 
d) are uncertain that 4- $\mathrm{H}$ is effective in promoting an environment conducive for inclusion of youth with ADHD, and

e) need training on the disorders and ways to make inclusion a success.

In a similar study, Brill (2011), through implementing a visual learning computer software program designed to reach special needs youth, advocated the need for Extension professionals to increase their awareness of individual learning styles in order to adapt teaching strategies an provide a variety of educational materials needed for special needs youth.

Research concerning the recruitment and retention of underrepresented groups in 4- $\mathrm{H}$ youth programs have yielded numerous suggestions regarding positive attitudes and participation. However, despite the successful research reports, youth of color and youth with disabilities by and large remain underrepresented in 4- $\mathrm{H}$ youth programs nationwide. As personal and demographical shifts continue to reshape the image of America's youth, it is important that 4-H programs continue to take the necessary steps to ensure equal and equitable programs. Given how much research has been dedicated towards successful inclusion efforts, researchers have yet to uncover practical solutions to diversity inclusive 4-H programs nationwide. This article attempts to answer this enigma by investigating strategies best sought after to increase diversity inclusion in 4-H programs.

\section{Conceptual Framework}

Building on the ideas that: (a) adolescents participating in youth programs demonstrate increased personal and social skills (Lee, Olszewski-Kubilius, Donahue, \& Weimholt, 2008; Wolchik, Schenck, \& Sandler, 2009), and (b) 4-H youth programs and the National FFA Organization share an interdisciplinary vision (Ricketts \& Bruce, 2009; Sulser, Greenhalgh, Parent, \& Sagers, 2012), the conceptual framework for this study was rooted in LaVergne's (2008) educational concept of Diversity Inclusion. According to the concept, diversity inclusion is an educational belief that accepts all learners by engaging them in learning programs regardless of their race, ethnicity, or exceptionally (LaVergne, 2008). Within the Model (see Figure 1), the principles of multicultural education (Banks, 2008), culturally responsive teaching (Gay, 2000), and Inclusion (Salend, 2008) are critically infused to create an educational professionals that: (

a) understand the benefits of inclusion,

b) accepts the fact that negative perceptions may influence underrepresented group participation in agriculturally-based programs, and

c) have an awareness of possible solutions to increase marginalized group participation.

In addition, to the three constructs the researcher states that the all-encompassing goal of a diversity inclusive program is to develop a learning culture that all students, regardless of their differences, experience social equity and equitable education (LaVergne, 2008).

Due to the concept's novelty, diversity inclusion research, particularly in regards to discovering strategies for diversity inclusive 4-H programs, is non-existent. In assessing secondary agricultural education teachers on proposed solutions to diversity inclusive programs, LaVergne, Jones, Larke, and Elbert (2012) discovered that participants favored promoting and fostering a diversity inclusive atmosphere in agricultural education programs. Participants were also in strong agreement regarding the support of underrepresented group participation, particularly youth of color, into the National FFA Organization. In addition, the researchers discovered that 
the development of learning strategies must take place in order to accommodate the diversity of learners among school aged youth.

Figure 1

The Diversity Inclusive Program Model (LaVergne, 2008, p. 44)

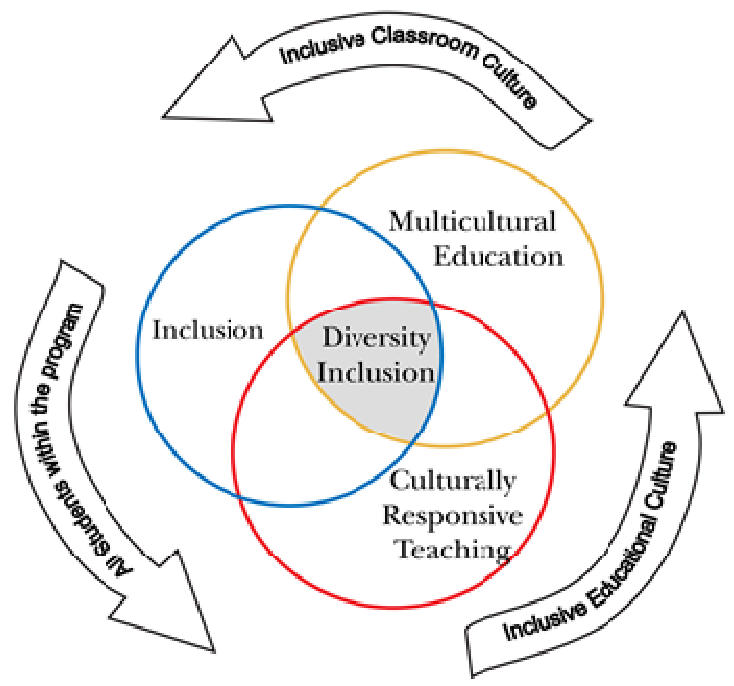

\section{Purpose and Objectives}

The purpose of this study was to explore and analyze [State] 4-H youth professionals' attitudes towards diversity inclusion in [State] $4-\mathrm{H}$ youth programs. The following objectives were identified to accomplish the purpose of the study:

1. Identify personal characteristics of the selected [State] 4-H youth professionals;

2. Determine [State] 4-H youth professionals' perceptions of proposed solutions to increase diversity inclusion in [State] $4-\mathrm{H}$ youth programs.

\section{Methods and Procedures}

This study utilized descriptive exploratory research. Survey research methods were used to collect information to describe [State] 4-H youth professionals' perceptions regarding proposed solutions to diversity inclusive 4-H youth programs. Following Dillman's (2007) Tailored Design Method for survey implementation, the researchers implemented a questionnaire using a series of e-mails while using SurveyMonkey.com as the host Web site. The questionnaire was based on previous work by LaVergne, Jones, Larke, and Elbert (2012) regarding Texas agricultural education teachers' perceptions on proposed solutions to increase diversity inclusion in agricultural education programs. Researchers acquired permission to use and modify the instrument. Thus, the instrument was slightly modified to have language appropriate for $4-\mathrm{H}$ and Extension audiences.

Part one consisted of 12 statements designed to gauge participants' perceptions on possible strategies or solutions that would promote diversity inclusion in 4-H youth programs. Participants responded to each question using a four point Likert-type scale wherein $1=$ strongly 
disagree, 2= disagree, $3=$ agree, and 4= strongly agree. Part two consisted of six items designed to collect demographic information on the 4-H Extension professionals. A statistical factor analysis was not conducted. Factors were determined conceptually by the research team, based on the borrowed instrument. Individual statements were identified conceptually as contributing to the construct. Cronbach's alpha coefficient was calculated and reported to describe the internal consistency of the summated scale. The reliability analysis coefficient for the construct was .89. Evidence of construct validity was collected from the responses and suggestions from the panel of experts and from a pilot test of 10 Extension professionals not included in the survey population. The group provided input regarding the content and direction of the statements which added to the accuracy and precise construction of the questionnaire.

The target population consisted of all [State] 4-H youth Extension professionals as listed through the [State] [University] Cooperative Extension Office during 2011-12. Because of the unavailability of accurate personal information (e.g., missing e-mail addresses, incorrect home/work addresses) from the three sources, access to all professionals was not feasible. The accessible population of the study consisted of all Extension professionals who had email addresses listed through the [State] [University] Cooperative Extension Office $(\mathrm{N}=1,400)$. Using a sampling formula from Bartlett, Kotrlik, and Higgins (2001), researchers randomly selected 276 participants $(n=276)$.

The questionnaire was administered using a series of e-mails. Participants received a prenotice/introductory letter outlining the purpose and importance of the study and informing them that they would receive an e-mail in about one week with instructions on how to complete the questionnaire online. From the preliminary selection, 24 e-mail addresses were invalid. To obtain valid e-mail addresses and to maintain number of participants, the researchers randomly selected additional participants from the total population pool. After this update, the e-mail addresses were deemed valid. For the data collection phase, the researchers sent reminder emails every Wednesday until the study was concluded. Non-response error was addressed by comparing respondents' questionnaire return rate prior to the closing date $(n=93)$ with respondents' questionnaire return rate after the closing date $(n=24)$ (Lindner, Murphy, \& Briers, 2001). Using the cutoff date as the independent variable and mean scores as the dependent variable, independent sample t-tests revealed that no statistically significant difference $(p<.05)$ between mean scores on the two constructs; therefore, the responding sample was deemed a representative sample of the accessible population. The final return rate was $42 \%$.

\section{Results}

Objective one was to identify personal characteristics of the selected [State] 4-H youth professionals. The majority of respondents were female $(75.7 \%)$ and of White/European American descent (93.4\%). About one-third (30.2\%) of the participants were $50-59$ years of age and about one-fourth (24.5\%) between the ages of $41-49$. A majority of the respondents had received diversity/multicultural training at the high school/college level (60.2\%) and over three-fourth of the participants received diversity/multicultural training at the career/work level (78.5\%). Regarding years of 4-H service, nearly one-fourth $(24.1 \%)$ of respondents had over 25 years of service while $19.4 \%$ had $6-10$ years of service (see Table 1 ). 
Table 1

Demographic Characteristics of Participants $(n=117)$

\begin{tabular}{|c|c|c|}
\hline & $n$ & $\%$ \\
\hline \multicolumn{3}{|l|}{ Gender $^{\mathrm{a}}$} \\
\hline Male & 26 & 24.3 \\
\hline Female & 81 & 75.7 \\
\hline \multicolumn{3}{|l|}{ Race/Ethnicity ${ }^{a}$} \\
\hline Biracial American & 2 & 1.9 \\
\hline Black/African American & 2 & 1.9 \\
\hline Hispanic/Latino American & 1 & 0.9 \\
\hline Native American & 2 & 1.9 \\
\hline White/European American & 100 & 93.4 \\
\hline \multicolumn{3}{|l|}{$\mathrm{Age}^{\mathrm{b}}$} \\
\hline $18-25$ Years of age & 5 & 4.7 \\
\hline $26-32$ Years of age & 16 & 15.1 \\
\hline $33-40$ Years of age & 13 & 12.3 \\
\hline $41-49$ Years of age & 26 & 24.5 \\
\hline $50-59$ Years of age & 32 & 30.2 \\
\hline $60+$ Years of age & 14 & 13.2 \\
\hline \multicolumn{3}{|c|}{ Diversity/Multicultural Training at high school/college level } \\
\hline Yes & 65 & 60.2 \\
\hline No & 43 & 39.8 \\
\hline \multicolumn{3}{|c|}{ Diversity/Multicultural Training at the career/work level ${ }^{a}$} \\
\hline Yes & 84 & 78.5 \\
\hline No & 23 & 21.5 \\
\hline \multicolumn{3}{|l|}{ Years of 4-H service (Adult) ${ }^{\mathrm{a}}$} \\
\hline 0 (<12 months $)-5$ Years of service & 19 & 17.6 \\
\hline $6-10$ Years of service & 21 & 19.4 \\
\hline $11-15$ Years of service & 19 & 17.6 \\
\hline $16-20$ Years of service & 9 & 8.3 \\
\hline $21-25$ Years of Service & 14 & 13.0 \\
\hline $25+$ Years of service & 26 & 24.1 \\
\hline
\end{tabular}

${ }^{a} 10$ participants did not to respond to question. ${ }^{b} 11$ participants did not respond to question.

${ }^{c} 9$ participants did not respond to question. ${ }^{d} 12$ participants did not respond to question.

Objective two was to determine [State] 4-H youth professionals' perceptions of proposed solutions to increase diversity inclusion in [State] 4-H youth programs. As depicted in Table 2, close to all respondents (98\%) strongly agreed or agreed to the statement: "County 4-H youth professionals should become familiar with the youth with disabilities represented in their counties in order to promote an atmosphere of acceptance and cooperation." In addition, $90 \%$ of respondents strongly agreed or agreed that: "All 4-H youth professionals should strive to increase a diverse membership in their 4-H youth programs." When asked whether 4-H youth professionals should become familiar with the youth of color represented in their counties in order to promote an atmosphere of acceptance and cooperation, $88 \%$ of respondents strongly agreed or agreed to the statement.

Four statements were presented to respondents concerning multicultural education initiatives that would aid in fostering diversity inclusive $4-\mathrm{H}$ youth programs. As depicted in Table 2, 94\% 
of respondents strongly agreed or agreed to the statement: "4- $\mathrm{H}$ youth instructional materials should reflect the diverse society that $4-\mathrm{H}$ youth programs have." In addition, $86 \%$ of respondents strongly agreed or agreed that: "Colleges and universities should incorporate more multicultural education classes in their preservice Extension preparation curriculums." While $71 \%$ strongly agreed or agreed that: "A multicultural education training workshop should be utilized to promote an attitudinal change toward diversity inclusion in 4-H youth programs." Regarding statewide initiatives, $90 \%$ of respondents strongly agreed or agreed to the statement: "For youth to become interested in joining 4-H, parents, 4-H youth professionals, and policymakers must develop strategies to address the different learning styles of all youth" and over three-fourths (77\%) of respondents strongly agreeing or agreeing to the statement: "A statewide support network designed to assist county 4-H youth professionals in working with diverse audiences would enhance diversity inclusion in 4-H."

Table 2

Participants' Ratings of Proposed Strategies to Increase Diversity Inclusion in 4-H Youth Programs $(n=117)$

\begin{tabular}{|c|c|c|c|c|}
\hline Diversity Inclusion & $\%$ SD & $\% \mathrm{D}$ & $\% \mathrm{~A}$ & $\% \mathrm{SA}$ \\
\hline \multicolumn{5}{|l|}{ 4-H Youth Professionals } \\
\hline $\begin{array}{l}\text { County } 4-\mathrm{H} \text { youth professionals should become familiar with the youth } \\
\text { with disabilities represented in their counties in order to promote an } \\
\text { atmosphere of acceptance and cooperation }\end{array}$ & -- & 2 & 74 & 24 \\
\hline $\begin{array}{l}\text { All 4-H youth professionals should strive to increase a diverse } \\
\text { membership in their 4-H youth programs }\end{array}$ & -- & 10 & 58 & 32 \\
\hline $\begin{array}{l}\text { County 4-H youth professionals should become familiar with the youth } \\
\text { of color represented in their counties in order to promote an } \\
\text { atmosphere of acceptance and cooperation }\end{array}$ & -- & 12 & 65 & 23 \\
\hline $\begin{array}{l}\text { An increase in the recruitment efforts of underrepresented groups by } \\
4-\mathrm{H} \text { professionals would enhance diversity inclusion in } 4-\mathrm{H}\end{array}$ & 1 & 11 & 72 & 16 \\
\hline $\begin{array}{l}\text { All 4-H youth professionals should be required to have some type of } \\
\text { diversity training prior to working with youth }\end{array}$ & 3 & 16 & 55 & 26 \\
\hline $\begin{array}{l}\text { Peer mentoring is a strategy that could be utilized to assist 4-H youth } \\
\text { professionals in increasing diversity inclusion }\end{array}$ & 2 & 17 & 63 & 17 \\
\hline \multicolumn{5}{|l|}{ Multicultural Education Initiatives } \\
\hline $\begin{array}{l}\text { 4-H youth instructional materials should reflect the diverse society that } \\
4-\mathrm{H} \text { youth programs have }\end{array}$ & -- & 6 & 61 & 33 \\
\hline $\begin{array}{l}\text { Colleges and universities should incorporate more multicultural } \\
\text { education classes in their preservice Extension preparation curriculums }\end{array}$ & 3 & 11 & 70 & 16 \\
\hline $\begin{array}{l}\text { A multicultural education training workshop should be utilized to } \\
\text { promote an attitudinal change toward diversity inclusion in 4-H youth } \\
\text { programs }\end{array}$ & 4 & 25 & 55 & 16 \\
\hline $\begin{array}{l}\text { County 4-H youth professionals need training in multicultural } \\
\text { education }\end{array}$ & 6 & 33 & 43 & 18 \\
\hline \multicolumn{5}{|l|}{ Statewide Initiatives } \\
\hline $\begin{array}{l}\text { For youth to become interested in joining } 4-\mathrm{H} \text {, parents, 4-H youth } \\
\text { professionals, and policymakers must develop strategies to address } \\
\text { the different learning styles of all youth }\end{array}$ & 1 & 9 & 54 & 36 \\
\hline $\begin{array}{l}\text { A statewide support network designed to assist county } 4-\mathrm{H} \text { youth } \\
\text { professionals in working with diverse audiences would enhance } \\
\text { diversity inclusion in 4-H }\end{array}$ & 3 & 20 & 61 & 16 \\
\hline
\end{tabular}




\section{Conclusions and Recommendations}

Although youth professionals not participating in this study may share similar perceptions, caution must be exercised when generalizing the results of this study. Overall, respondents from the sample population had a moderate rate of response using an Internet/e-mail centered survey method. This finding add credence to previous studies that concluded that web-based survey instruments are valid and reliable methods for collecting data (Ladner, Wigenbach, \& Raven, 2002; LaVergne, Jones, Larke, \& Elbert, 2012). The majority of 4-H youth professionals had received some form of diversity/multicultural education training either at the high school/college (60.2\%) or career/work level (78.5\%). This percentage increase from high school/college level training to career/work training could indicate that the [State] Cooperative Extension Service is making conscious efforts to ensure that all Extension professionals are trained to address the ever-growing diversity of youth in the country.

Participants responded favorably to all statements listed in the questionnaire. Based on this finding, it can be concluded that [State] 4-H youth professionals recognize the need for practical strategies to increasing diversity inclusion in 4-H youth programs. From the findings, it can also be concluded that there are benefits to diverse audiences in 4-H youth programs. Because this study addressed both youth of color and youth with disabilities, findings of this study support previous research favoring diversified 4-H youth programs (Alston, \& Crutchfield, 2009; Goble, \& Eyre, 2008; Lippert, \& Rembert, 2012; Newby, \& Sallee, 2011).

Respondents agreed that the recruitment efforts of underrepresented groups should be improved to enhance diversity inclusion in 4-H youth programs. Perusing previous research regarding Extension professionals' efforts to recruit and retain diverse audiences in 4-H has revealed a multitude of programs and initiatives. Although most researchers have reported on the success of these programs, the fact remains that in many mainstream programs, marginalized youth continue to be excluded and the barriers to inclusion often remain unresolved (Peterson, et al., 2012; Russell, \& Van Campen, 2011). In order for 4-H youth programs to create authentically diverse organizations, $4-\mathrm{H}$ youth professionals must examine the original intent of county level programs and determine why certain groups are underrepresented. Russell and Van Campen (2011) propose a thought-provoking view:

Youth become marginal from the mainstream in ways that are often invisible because the mainstream appears "normal." However, if we consider dominant culture as a collection of peculiar norms and habits (habits that are only "normal" because they are dominant), we may begin to uncover and understand processes of marginalization. In doing so, the question is no longer "why aren't marginal youth present?" but "what is it about programs and institutions that enables marginalization?" (p.104)

The call for diversifying 4-H youth programs must be an all-in approach whereby 4-H youth professionals are ready to accept the challenge of embracing and valuing all youth. Reports indicate that when diversity is valued, attitudes, behaviors, and expectations can change (Broadwater, 2001; Rodrigues, 2000). In addition, 4-H youth professionals must realize that although marginalized populations may be similar on the surface, what works for one group may not have the same impact on another. Providing inclusive programs must start with professionals who are committed to becoming "locally" culturally competent in order to recruit and retain diverse audiences. Understanding the personal and social characteristics of the 
underrepresented groups in our counties is the first step in building equitable programs. Once this has been established only then will our efforts to build diversity inclusive programs succeed.

Respondents agreed that a statewide support network to assist 4-H youth professionals in working with diverse audiences would enhance diversity inclusion in $4-\mathrm{H}$. This finding, combined with the high percentage of respondents favoring peer mentoring $(88 \%)$, indicates the need for additional training regarding diversity inclusion. Specific attention to the training and development of 4-H extension workers' abilities to work with diverse audiences has been thoroughly noted throughout the literature. In addition, researchers have also discovered that, when compared to their collegial counterparts, 4-H personnel typically have been less ethnically diverse and less likely to have worked with underrepresented groups (Evans, Sicafuse, \& Killian, 2009). Moreover, Peterson, et al. (2012) discovered that many Extension professional tend to receive their inclusion training in preservice programs where acute focus to accommodating special need individuals was not a prioritize objective. This lack of cultural experience among 4-H workers combined with the rapidly changing demographics will only perpetuate the marginalization of diverse groups in $4-\mathrm{H}$ youth programs. Based on the findings, it is recommended that 4-H youth professionals develop organized support groups with other youth base programs to determine practical strategies for underrepresented group participation. One place where 4-H professionals may look is local schools. Because schools play a critical role in assisting the bridging of diverse cultures (Ridings, et al., 2011), it would be wise for 4-H youth professionals to partner with local school organizations to gain experience toward working with diverse individuals in a formal setting. Additionally, the partnership could bring awareness to the benefits of $4-\mathrm{H}$ program participation.

Respondents agreed that for youth to become interested in joining 4- $\mathrm{H}$, parents, $4-\mathrm{H}$ youth professionals, and policymakers must develop strategies to address the different learning styles of all youth. Although 4-H youth programs have made strides in addressing disabilities, research indicates that 4-H professionals are still lacking the abilities to promote all-inclusive 4-H environments (Mpofu, Ingram, \& Radhakrishna, 2011; Peterson, et al., 2012). Given that nearly one of every 5 people in the United States ages 5 and older have some form of disability (Brault, 2012), it is ever more important that Extension professionals are prepared to address diversity so that adaptations could be implement to maximize youth participation (Brill, 2011). Based on this finding it is recommended that 4-H youth professionals engage in in-service training programs to develop practical strategies for accommodating the multiple learning styles of 4-H youth. This in-service training could be provided by a number of entities such as

a) county-level special service coordinators,

b) university-level disability support services,

c) school-based special education instructional coaches, and

d) state-level offices of special programs.

Activities to improve 4-H youth professionals' understanding of child development, specific educational needs of the most common learning disabilities, and procedural initiatives to recruit and retain diverse members could be implemented. Additionally, trainings could be independent or collaborative based on the amount of information presented.

Finally, this study makes a contribution to the expanding literature related to recruiting and retaining diverse members in $4-\mathrm{H}$ youth programs on two levels. First it provides a successful example of a structured framework that other 4-H researchers can use for engaging Extension professionals in diversity inclusive research. Secondly, this study produced a visual 
representation of 4-H youth professionals' attitudes towards proposed solutions to diversifying 4-H youth programs. The process by which individual strategies were developed through this study may also assist future researchers in prioritizing three important constructs in fostering diversified 4-H programs: inclusion, multicultural education, and culturally responsive teaching.

\section{References}

4-H National Headquarters. (2012). 2010 4-H youth development es-237 statistics. Available at: http://www.national4-hheadquarters.gov/library/FS-ES237-2010.pdf

Alston, A.J., \& Crutchfield, C.M. (2009). A descriptive analysis of the perceptions of North Carolina 4-H agents toward minority youth participation in agricultural-related activities. Journal of Extension, 4オ5), 5RIB5. Available at: http://www.joe.org/joe/2009october/rb5.php

Banks, J.A. (2008). An introduction to multicultural education. Boston, MA: Allyn and Bacon.

Bartlett, J.E. II, Kotrlik, J.W., \& Higgins, C.C. (2001). Organizational research: Determining appropriate sample size in survey research. Information Technology, Learning, and Performance Journal, 19(1), 43-50.

Brault, M.W. (2012). Americans with disabilities: 2010. Available at: http://www.census.gov/prod/2012pubs/p70-131.pdf

Brill, M.F. (2011). Teaching the special learner: When words are not enough. Journal of Extension, 49(5), 5TOT4. Available at: http://www.joe.org/joe/2011october/tt4.php

Broadwater, G. (2001). Valuing diversity in 4-H. Available at:

http://www.ca.uky.edu/agcollege/4h/oldsite/gems/edpdf/Diversity.pdf

Dillman, D.A. (2007). Mail and internet surveys: The tailored design method. Hoboken, NJ: John Wiley \& Sons, Inc.

Evans, W.P., Sicafuse, L.L., \& Killian, E. (2009). 4-H youth worker characteristics: Comparisons with workers from other youth-serving organizations. Journal of Extension, 4Л6), 6RIB4. Available at: http://www.joe.org/joe/2009december/rb4.php

Gay, G. (2000). Culturally responsive teaching: Theory, research, and practice. New York, NY: Teachers College Press.

Goble, C.L., \& Eyre, N.S. (2008). Incorporating special needs youth into 4-H. Journal of Extension, 46(6), 6IAW2. Available at: http://www.joe.org/joe/2008december/iw2p.shtml

Ladner, M., Wingenbach, G., \& Raven, M. (2002). Internet versus paper based data collection methods. Proceedings of the Southern Agricultural Education Research Conference, 52, 40-51. Available at: http://pubs.aged.tamu.edu/jsaer/pdf/vol52/52-02-040.pdf

LaVergne, D.D. (2008). Perceptions of Texas agricultural education teachers regarding diversity inclusion in secondary agricultural education programs. Unpublished doctoral dissertation. Texas A\&M University, College Station, TX. 
LaVergne, D.D. (in press). Diversity inclusion in 4-H youth programs: Examining the perceptions among West Virginia 4-H youth professionals. Journal of Extension. Available at:

http://www.joe.org/index.php

LaVergne, D.D., Jones, W.A., Larke, Jr., A., \& Elbert, C.E. (2012). Identifying strategies for diversity inclusive agricultural education programs. North American Colleges \& Teachers of Agriculture Journal, 56(2), 47-54.

Lee, S.Y., Olszewski-Kubilius, P., Donahue, R., \& Weimholt, K. (2008). The civic leadership institute: A service-learning program for academically gifted youth. Journal of Advanced Academics, 19, 272-308.

Lindner, J.R., Murphy, T.H., \& Briers, G. (2001). Handling nonresponse in social science research. Journal of Agricultural Education, 42(4), 43-53. doi: 10.5032/jae.2001.04043

Lippert, R., \& Rembert, K. (2012). South Carolina's model for initiating Hispanic 4-H clubs. Journal of Extension, 50(6), 6IAW5. Available at:

http://www.joe.org/joe/2012december/iw5.php

Mpofu, C., Ingram, P.D., \& Radhakrishna, R. (2010). Perceptions of 4-H extension educators and volunteer leaders towards the inclusion of youth with attention deficit hyperactive disorder(s) in 4-H programs. Journal of Youth Development, 5(1), Article 100501FA002. Available at: http://nae4a.memberclicks.net/assets/documents/jyd summer2010.pdf

Newby, L., \& Sallee, J. (2011). 4-H membership recruitment/retention problems: A metaanalysis of possible causes and solutions. Journal of Youth Development, 6(4), Article 110604FA003. Available at: http://nae4a.memberclicks.net/assets/documents/JYD 0604final.pdf

Nicolas, G., DeSilva, A.M., Houlahan, S., \& Beltrame, C. (2009). Culturally authentic scaling approach: A multi-step method for culturally adapting measures for use with ethnic minority and immigrant youth. Journal of Youth Development, 4(1), Article 090401FA006. Available at: http://nae4a.memberclicks.net/assets/documents/JYD 090401final.pdf

Peterson, R.L., Grenwelge, C., Benz, M.R., Zhang, D., Resch, J.A., Mireles, G., et al. (2012). Serving clientele with disabilities: An assessment of Texas FCS agents' needs for implementing inclusive programs. Journal of Extension, 50(6), 6FEA7. Available at:

http://www.joe.org/joe/2012december/a7.php

Ricketts, K.G., \& Bruce, J.A. (2009). "Co-opetition?" can it exist between extension and agricultural education-a study on interdisciplinary cooperation. Journal of Extension, 4Х5), 5RIB1. Available at: http://www.joe.org/joe/2009october/rb1.php

Ridings, J.W., Piedra, L.M., Capeles, J.C., Rodriguez, R., Freire, F., \& Byoun, S. (2011). Building a Latino youth program: Using concept mapping to identify community-based strategies for success. Journal of Social Service Research, 37, 34-39.

Rodrigues, L. (2000). Multicultural challenges in 4-H youth development: Bridging the divide. Available at: http://www.extension.umn.edu/distribution/youthdevelopment/00062.pdf 
Russell, S.T., \& Van Campen, K. (2011). Diversity and inclusion in youth development: What we can learn from marginalized young people. Journal of Youth Development, 6(3), 95-108, Article 110603FA006. Available at:

http://nae4a.memberclicks.net/assets/documents/JYD 110603final.pdf

Salend, S.J. (2008). Creating inclusive classrooms: Effective and reflective practices. (6th ed.). Upper Saddle River, NJ: Pearson Prentice Hall.

Snyder, T.D., \& Dillow, S.A. (2011). Digest of educational statistics 2010 (NCES 2011-015). National Center for Education Statistics, Institute of Education Sciences, U.S. Department of Education. Washington, DC.

Stair, K.S., Seevers, B.S., \& Moore, A. (2012). State 4-H leader's perceptions of involvement of youth with special needs in the 4-H program. Journal of Youth Development, 73 ), Article 120703FA004. Available at: http://nae4a.memberclicks.net/assets/documents/jyd 0703.pdf

Sulser, A., Greenhalgh, L., Parent, V., \& Sagers, S. (2012). Utah 4-H and FFA relationships dynamics. Journal of the $N A C A A, 5(1)$. Available at: http://www.nacaa.com/journal/index.php?jid=125

Wolchik, S.A., Schenck, C.E., \& Sandler, I.N. (2009). Promoting resilience in youth from divorced families: Lessons learned from experimental trials of the new beginnings program. Journal of Personality, 77, 1833-1868.

(C) Copyright of Journal of Youth Development $~$ Bridging Research and Practice. Content may not be copied or emailed to multiple sites or posted to a listserv without copyright holder's express written permission. Contact Editor at: patricia.dawson@oregonstate.edu for details. However, users may print, download or email articles for individual use.

ISSN 2325-4009 (Print); ISSN 2325-4017 (Online) 